Patella et al. Figure S2

A

FITC-albumin permeability

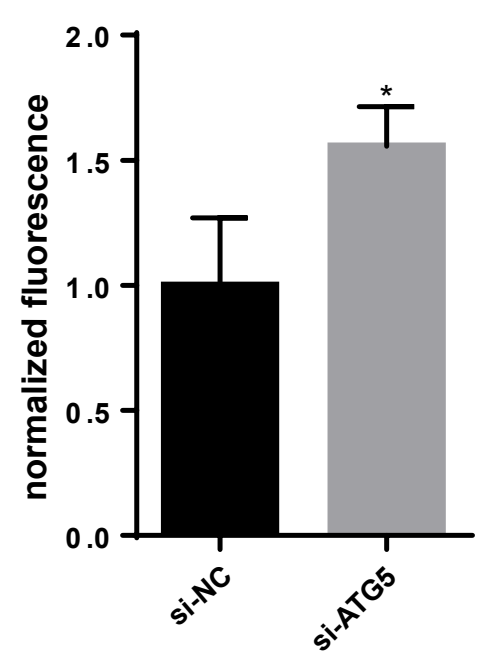

C

FITC-albumin permeability

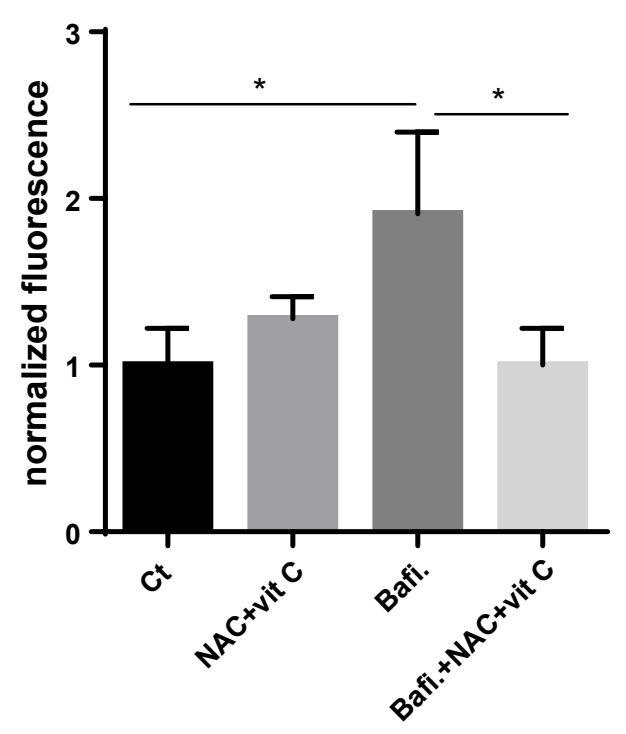

B

\section{FITC-albumin permeability}

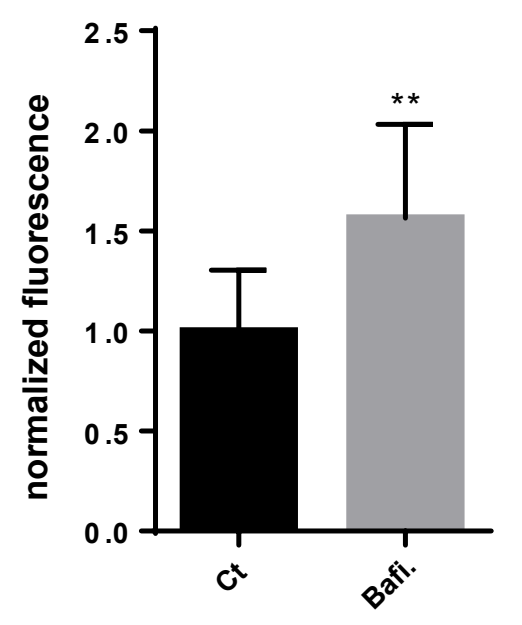

